\title{
MODERN APPROACH TO THE RETINOPATHY OF PREMATURITY TREATMENT
}

\author{
Tatjana Sarenac Vulovic 1,2, Suncica Sreckovic1,2, Nenad Petrovic1,2, Mirjana Janicijevic Petrovic1,2, Svetlana Jovanovic1,2, \\ Dusan Todorovic ${ }^{2}$ \\ ${ }^{1}$ Clinic of Ophthalmology, Clinical Centre Kragujevac, Kragujevac, Serbia \\ ${ }^{2}$ Department of Ophthalmology, Faculty of Medical Sciences, University of Kragujevac, Kragujevac, Serbia
}

\section{SAVREMENI PRISTUP U LEČENJU RETINOPATIJE PREMATURITETA}

\author{
Tatjana Šarenac Vulovićl,2, Sunčica Srećkovićl,2, Nenad Petrovićl,2, Mirjana Janićijević Petrovićl,2, Svetlana Jovanovićl,2, \\ Dušan Todorović ${ }^{2}$ \\ ${ }^{1}$ Klinika za oftalmologiju, Klinički centar Kragujevac, Kragujevac \\ ${ }^{2}$ Katedra za oftalmologiju, Fakultet medicinskih nauka, Univerzitet u Kragujevcu, Kragujevac
}

\begin{abstract}
Retinopathy of prematurity is a proliferative retinopathy that occurs in prematurely born children. It is still the leading cause of preventable childhood blindness worldwide. The aim of this paper is to present the therapeutic modalities for the retinopathy of prematurity. Current gold standard treatment is the laser photocoagulation of avascular retina in order to reduce its existing hypoxia. By expanding our knowledge of the pathogenesis of petinopathy of prematurity, and the knowledge of the laser therapy efficiency and complications as well, new therapeutic options appear (intravitreal application of anti VEGF, gene therapy and administration of supplements). In order to avoid the visual function loss in prematures caused by retinopathy of prematurity, screening of the premature newborn is the first choice.
\end{abstract}

Key words: retinopathy of prematurity; vascular endothelial growth factors; antibodies, monoclonal, humanized.

\section{INTRODUCTION}

Retinopathy of prematurity (ROP) is a multifactorial, vasoproliferative disease which is the leading cause of preventable childhood blindness, both in developing and developed countries. The difference in incidence and risk factors (1) is made according to the degree of the development of health care system (perinatal care, screening criteria) and race (2-6). World Health Organization gave great significance to ROP control by introducing the protocol for following up prematurely born children - 'Vision 2020 Programme' (7). Anti VEGF therapy is good choice with great effects for the treatment of the active form of ROP.

\section{PATHOGENESIS}

ROP is a biphasic disease. In the first phase hyperoxy and obliteration of blood vessels can be detected. The second is presented with hypoxia and neovascularization $(8,9)$. Retinal vascularization starts in the 16th week of gestation and finishes soon after birth. The birth of the

\section{SAŽETAK}

Retinopatija prematuriteta je proliferativna retinopatija koja se javlja kod prevremeno rođene dece. Ona još uvek predstavlja vodeći uzrok preventabilnog slepila dečijeg doba šrom sveta. Cilj ovog rada je da prezentuje terapijske mogućnosti retinopatije prematuritete. Trenutni zlatni standard u lečenju je laserska fotokoagulacija avaskularne retine radi smanjenja nastale hipoksije. Širenjem naših saznanja o patogenezi retinopatije prematuritete, kao $i$ saznanja o efikasnosti $i$ komplikacijama laserske terapije, pojavljuju se nove terapijske mogućnosti (intravitrealna aplikacija anti-VEGF faktora, genska terapija $i$ primena suplemenata). Radi izbegavanja gubitka vidne funkcije prematurusa izazvanog retinopatijom prematuritetom, prvi izbor predstavlja skrining prevremeno rođene dece.

Ključne reči: retinopatija nedonoščadi; vaskularni endotelni faktori rasta; antitela, monoklonska, humanizovana.

child means the transitions in relative hyperoxic environment with possibly added oxygen. Hyperoxigen conditions make the developing of the obliteration and the discontinuation of the already developed retinal blood vessels. That is the first ROP phase that lasts from birth till the $30^{\text {th }}-31^{\text {st }}$ week of gestation (9). Further retinal development demands more oxygen because of its increased growth and metabolic processes. Immature, ischemic retinal zones become more hypoxic and stimulate the hyper production of vascular endothelial growth factor (VEGF), which results in the abnormal retinal neovascularization. That is the second ROP phase that starts from the $31^{\text {st }}-32^{\text {nd }}$ week of gestation $(10,11)$. In that phase the insulin-like growth factor (IGF) has a prominent role. Its secretion is in tight conjunction with the gestational age and newborn's weight. VEGF and IGF are synergists. IGF has a role in the process of normal vascularization. Also, it regulates retinal neovascularization by controlling VEGF activation regardless of oxygenation (11). Low serum level of IGF stops blood vessels development, and it is the predictor of ROP $(12,13)$. The serum level of IGF is the indicator of 
other tissues` condition-liver, the uterus, the placenta. Its low serum level can be the indicator of a sick child even without the ROP risk (14).

\section{CLASSIFICATION}

International Classification of Retinopathy of Prematurity (ICROP) used: presenting zone, intensity of ROP and stage (15).

Severeness of the ROP changes is determined in relation to (Figure 1)

1. Localization

a) $1^{\text {st }}$ zone that includes optic disc (PNO), with radius of two PNO-macula lengths

b) $2^{\text {nd }}$ zone includes the area till ora serrata nasally

c) $3^{\text {rd }}$ zone radius includes the area till the ora serrata temporally

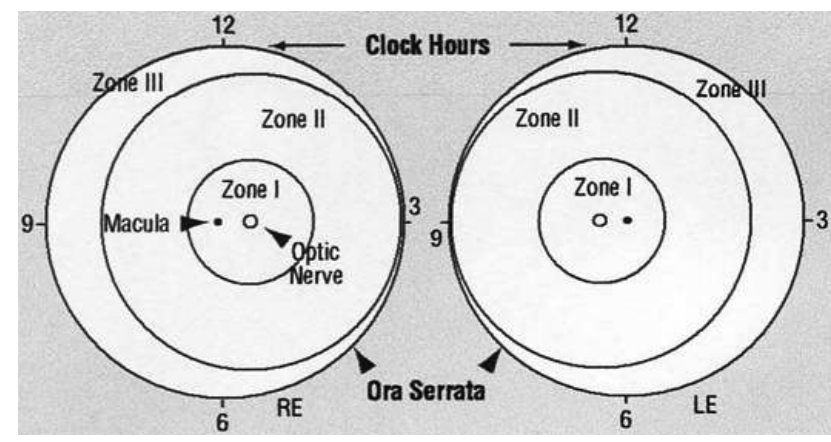

2. Expansion presents changes determined by the portion of the affected retina in relation to the clock hours

3. Stages

a) stage 1 refers to the demarcation line that represents the first pathognomonic sign of ROP

b) stage 2 is represented by the reef

c) stage 3 is the reef with extraretinal fibrovascular proliferation

d) stage 4 represents subtotal retinal ablation with or without infecting the macula

e) stage 5 is represented by the total retinal ablation

4. 'Plus' disease - the impossibility of the dilation of the pupil with the expanded blood vessels of the iris, blurred vitreous visualization, venous dilatation and arterial tortuosity at fundus, and preretinal and vitreous hemorrhage (16).

Screening is performed in the cases of highly risked prematures of a younger gestational age at birth, small body weight at birth, or those that were exposed to oxygen with a partial pressure higher than $1 \%$ for a longer period of time in special units of pediatric clinics. Controls are conducted till retinal vascularization is finished. Screening process is performed in mydriasis, 4-6 weeks after birth, when ROP condition is determined. This fundus finding determine control rhythm and urgency as well as the need for treatment. In reference to that, the disease according to the degree of urgency is divided into three groups:

1.Threshold disease - represents stage 3 in the $1^{\text {st }}$ or $2^{\text {nd }}$ zone with at least 5 tied or 8 untied hours, and demands necessary treatment;

2. Pre-threshold disease - represents the $1^{\text {st }}$ zone at any ROP stage with 'plus' disease, the $1^{\text {st }}$ zone at stage 3 with or without 'plus' disease or the $2^{\text {nd }}$ zone at $2 / 3$ stage with 'plus' disease, demands further screening;

3. Rush disease - refers to the progressive ROP form (posterior location, dilated retinal blood vessels with shunt) that demands urgent therapeutic treatment.

\section{MODALITIES OF THE ROP TREATMENT}

The laser photocoagulation of the avascular retina, whether the laser photocoagulation (argon or diode laser) or cryotherapy, still remains the gold standard for ROP treatment from the $1^{\text {st }}$ to the $3^{\text {rd }}$ stage and for the aggressive posterior retinopathy forms (18). This treatment must be performed by competent ophthalmologist in topical anesthesia with transpupillary or trans-scleral approach. Subsequent to application, an early complete regression of extraretinal proliferation is observed (19). Some other complications have been reported, such as: the early ones - corneal edema, intraocular hemorrhage, ocular hypertension and the late ones - significant narrowing of peripheral vision as a consequence of retinal cells necrosis, high degree myopia, glaucoma, retinal detachment, strabismus. Despite of all the above mentioned, the only approved ROP therapy is the laser photocoagulation combined with vitreoretinal surgery (scleral buckling or pars plana vitrectomy), depending on the severity of the disease.

There are also several new therapeutic modalities for ROP treatment, such as anti-VEGF (20-25), systemic propranolol $(26,27)$, gene therapy (28), IGF (29), dietary supplementation with omega- 3 fatty acids and vitamin $\mathrm{E}$ $(30,31)$.

\section{ANTI-VEGF THERAPY}

VEGF is a potent mitogen for vascular endothelial cells, whose secretion depends on the tissue hypoxia (10), for physiological and pathological angiogenesis. The aim of anti-VEGF therapy is to block the effect of VEGF on pathological retinal vascularization, but without the destruction of tissues of retina and the vitreus. It is applied in clinical conditions, in local anesthesia. The amount of $0.1 \mathrm{ml}$ of drug is applied $4 \mathrm{~mm}$ from the limbus under the control of the magnifier of 20D strength. Currently available medicines are ranibizumab (®Lucentis), bevacizumab (®Avastin), pegaptanib natrium (®Macugen) 
and aflibercept (®Eylea). FDA approved ranibizumab, pegaptanib natrium and aflibercept for intraocular application in adults (32). The first approved medicine for the treatment of senile macular degeneration is pegaptanib natrium. However, there are several described cases in which intravitreal application of pegaptanib at the ROP stage $3+$ led to successful results without any systemic or ocular complications during the following period of 19 months (33). Ranibizumab has a shorter half-life in the serum than bevacizumab, so theoretically it probably causes less undesirable systemic effects in new born children. The aflibercept has a longer half-life than all antiVEGF medicines. The number of described cases with intravitreal anti-VEGF application is constantly increasing in the literature. Lee et al. described great benefit of anti VEGF intravitreal applied as regression of neovascularization and the continuation of a normal vascularization, without the appearance of complications or the reactivation of the disease within the period of 3 years during which the children were followed up (24). Other data suggested that anti VEGF intravitreal applied may cause systemic complications because of the known VEGF influence for the physiological development of the brain, the lungs, the kidneys (34). In addition, the following systemic complications were observed: hypertension, a transient ischemic attack, pulmonary hypertension, tromboemboly, cerebrovascular insult and death (35). The reported local complications are endophthalmitis, retinal ruptures, a severe uveitis, intraocular hypertension, glaucoma, cataract (35). Using of anti VEGF as monotherapy or additional therapy is the matter of local findings and the choice of ophthalmologist (36).

\section{PROPRANOLOL}

Propranolol applied systemicaly decrease the level of the VEGf, which can be useful in the ROP treatment (37). Prospective studies in which the new born children were treated with propranolol per os, showed that $48 \%$ of them decreased the risk of the third stage development, $58 \%$ of them decreased the progression into stage $3+$, and $100 \%$ decreased the progression into the 4th stage (37). However, propranolol has serious undesirable effects such as bradycardia, branch block, hypotension, bronchospasm, hypoglycemia, dyslipidemia (38), which can be very harmful in prematures. Therefore, before the propranolol application, the usefulness and safety for every individual case should be considered. Additionally, it is necessary to mention that the effect of propranolol has still to be examined.

\section{GENE THERAPY}

Gene therapy influences numerous cytokines and growth factors activity, that are known to participate in the ROP pathogenesis. It is considered to be included in the therapy of ROP. Chowers et al showed its efficacy in the ROP regression in rat model (39), but the safety of the gene therapy application in prematures and its possible effects on a child's development are uncertain and should be completely evaluated (40).

\section{THE ADDITIONAL THERAPY}

1. Omega-3 polyunsaturated fatty acids transmit through placenta from the mother to baby, in the third trimester of pregnancy. This phenomenon does not occur in prematures. In the conducted study on the mice with ROP, the application of omega-3 polyunsaturated fatty acids showed in the $50 \%$ of cases a protective effect against a pathological neovascularization (41), but it is necessary to conduct more clinical trials to confirm the safety of the application in prematures.

2. Based on reachable data, erythropoietin is angiogenic growth factor depending on the oxygen concentration, with the effects similar to VEGF (42). However, the role of erythropoietin in the normal human retinal vasculogenesis has not been known yet (42).

3. IGF-1 is the oxygen-independent growth factor important for normal retinal vascularization. It acts by regulating the VEGF signalization. Its level increases mostly in the third pregnancy trimester and decreases sharply after birth. This fact can be explained by its production in placenta and fetal liver. In prematures, low IGF level is associated with the discontinuation of vascularization and the development of ROP $(16,17)$. By using a IGF-1 receptor antagonist, neovascularization is suppressed and normal retinal vasculogenesis continues (43), but there are no studies that confirm its safe application in prematures.

4. Granulocyte colony-stimulating factor (GCSF) is a biological cytokine that increases the IGF-1 level, which supports normal vasculogenesis. In that way GCSF promotes angiogenesis in the ischemic retina without any negative effects on VEGF (44).

5. Vitamin E. Antioxidative system is functionally immature in prematures that are susceptible to oxidative stress and the development of the disease connected to the oxygen concentration such as ROP. Nevertheless, the results of meta-analysis of random studies with the supplementation of vitamin $\mathrm{E}$ are contradictory: vitamin $\mathrm{E}$ supplementation didn't lead to the decrease of the risk for ROP, even the risk for sepsis development and necrotizing enterocolitis is increased (45).

\section{CONCLUSION}

The frequency of ROP is different in numerous studies, but the progress of neonatal intensive care and the increased survival of prematurely born children have led to the increased rate of ROP that demands screening and 
treatment (1-8). The prevention of the development of the severe ROP forms is the best strategy at the moment in order to avoid the damage of visual function, even blindness. Current gold standard treatment for a proliferative ROP is the panretinal laser photocoagulation, but it's not ideal due to the damage of peripheral vision and possible high degree myopia. However, countless studies have been conducted that examine the safety and efficiency of antiangiogenic therapy, anti-VEGF in the first place, in prematures. The results of those studies are encouraging and valuable for the new ROP therapeutic modules in the near future.

\section{ABBREVIATIONS}

IGF - insulin-like growth factor

FDA - food and drug administration

GCSF - Granulocyte colony- stimulating factor

ROP - retinopathy of prematurity

VEGF - vascular endothelial growth factor

\section{REFERENCES}

1. Akçakaya AA, Yaylali SA, Erbil HH, et al. Screening fir retinopathy of prematurity in a tertiary hospital in Istanbul: incidence and risk factors. J Pediatr Ophthalmol Strabismus 2012; 49: 21-5.

2. Mutlu FM, Sarici SU. Retinopathy of prematurity: incidence and risk factors. Expert Rev Ophtalmol 2007; 2: 267-74.

3. Palmer EA, Flynn JT, Hardy RJ, et al. Incidence and early course of retinopathy of prematurity: The Cryotherapy for Retinopathy of Prematurity Cooperative Group. Ophthalmology. 1991; 98: 1628-40.

4. Hoogerwerf A, Schalij-Delfos NE, van Schooneveld MJ, Termote JUM. Incidence of retinopathy of prematurity over the last decade in the Central Netherlands. Neonatology 2010; 98: 137-42.

5. Phan MH, Nguyen PN, Reynolds JD. Incidence and severity of retinopathy of prematurity in Vietnam, a developing middle-income country. J Pediatr Ophthalmol Strabismus 2003; 40: 208-12.

6. Mutlu FM, Altinsoy HI, Mumcuoglu T, et al. Screening for retinopathy of prematurity in a tertiary care newborn unit in Turkey: frequency, outcomes, and risk factor analysis. J Pediatr Ophthalmol Strabismus 2008; 45: 291-8.

7. Gilbert C, Foster A. Childhood blindness in the context of VISION 2020 - the right to sight. Bull World Health Organ 2001; 79: 227-32.

8. Heckmann M. Pathogenesis of retinopathy of prematurity. Ophthalmologe 2008; 105: 1101-7.
9. Castellanos MAM, Schwartz S, Garcia-Aguirre G, Quiroz-Mercado H. Short-term outcome after intravitreal ranibizumab injections for the treatment of retinopathy of prematurity. Br J Ophtalmol 2013; 97: 816-9.

10. Smith EL, Hard AL, Hellstrom. The biology of retinopathy of prematurity: how knowlwdge of pathogenesis guides treatment. Clin Perinatol 2013; 40: 201-14.

11. Smith LE. Pathogenesis of retinopathy of prematurity. Semin Neonatol 2003; 8: 469-73.

12. Young TL, Anthony DC, Pierce E, Foley E, Smith LE. Histopathology and vascular endothelial growth factor in untreated and diode laser-treatedretinopathy of prematurity. J AAPOS 1997; 1: 105-10.

13. Colakoğlu O, Taşkiran B, Colakoğlu G, et al. Serum insulin like growth factor-1 (IGF-1) and insulin like growth factor binding protein-3 (IGFBP-3) levels in liver cirrhosis. Turk J Gastroenterol 2007; 18: 245-9.

14. Serrano ML, Romero A, Cendales R, Sánchez-Gómez M, Bravo MM. Serum levels of insulin-like growth factor-I and -II and insulin-like growth factor binding protein 3 in women with squamous intraepithelial lesions and cervical cancer. Biomedica 2006; 26: 258-68.

15. Gole AG, Ells AL, Katz X, et al. The international classification of retinopathy of prematurity revisited. Arch Ophtalmol 2005; 123: 991-9.

16. Sonmez K, Drenser KA, Capone A, Jr, Trese MT. Vitreous levels of stromal cell-derived factor 1 and vascular endothelial growth factor in patients with retinopathy of prematurity. Ophtalmology 2008; 115 : 1065-70.

17. Löfqvist C, Andersson E, Sigurdsson J, et al. Longitudinal postnatal weight and insulin-like growth factor I measurements in the prediction of retinopathy of prematurity. Arch Ophtalmol 2006; 124: 1711-8.

18. Landers MB $3^{\text {rd }}$, Toth CA, Semple HC, Morse LS. Treatment of retinopathy of prematurity with argon laser photocoagulation. Arch Ophtalmol 1992; 110: 44-7.

19. Kanski JJ. Clinical Ophthalmology. 5th ed. Elsevier; 2003: 473-8.

20. Travassos A, Teixeira S, Ferreira P, et al. Intravitreal bevacizumab in aggressive posterior retinopathy of prematurity. Ophthalmic Surg Laser Imag 2007; 38: 233-7.

21. Chung EJ, Kim JH, Ahn HS, Koh HJ. Combination of laser photocoagulation and intravitreal bevacizumab (Avastin) for aggressive zone I retinopathy of prematurity. Graefes Arch Clin Exp Ophtalmol 2007; 245: $1727-30$. 
22. Mintz-Hittner HA, Kuffel RR. Intravitreal injection of bevacizumab (avastin) for treatment of stage 3 retinopathy of prematurity in zone I or posterior zone II. Retina 2008; 28: 831-8.

23. Altinsoy HI, Mutlu FM, Gungor R, Sarici SU. Combination of laser photocoagulation and intravitreal bevacizumab in aggressive posterior retinopathy of prematurity. Ophthalmic Surg Lasers Imaging 2010; 1-5.

24. Lee JY, Chae JB, Yang SJ, Yoon YH, Kim JG. Effects of intravitreal bevacizumab and laser in retinopathy of prematurity therapy on the development of peripheral retinal vessels. Graefes Arch Clin Exp Ophtalmol 2010; 248: 1257-62.

25. Mintz-Hittner HA, Kennedy KA, Chuang AZ, BEATROP Cooperative Group Efficacy of intravitreal bevacizumab for stage 3+ retinopathy of prematurity. N Engl J Med 2011; 364: 603-15.

26. de Graaf M, Breur JM, Raphaël MF, Vos M, Breugem CC, Pasmans SG. Adverse effects of propranolol when used in the treatment of hemangiomas: a case series of 28 infants. J Am Acad Dermatol 2011; 65: 320-7.

27. Filippi L, Cavallaro G, Fiorini P, et al. Study protocol: safety and efficacy of propranolol in newborns with Retinopathy of Prematurity (PROP-ROP): ISRCTN18523491. BMC Pediatr 2010; 10:83.

28. Hard AL, Hellstrom A. On the use of antiangiogenetic medications for retinopathy of prematurity. Acta Paediatr 2011; 100: 1063-5.

29. Löfqvist C, Niklasson A, Engström E, et al. A pharmacokinetic and dosing study of intravenous insulin-like growth factor-I and IGF-binding protein-3 complex to preterm infants. Pediatr Res 2009; 65: 574-9.

30. Stahl A, Sapieha P, Connor KM, et al. Short communication: PPAR gamma mediates a direct antiangiogenic effect of omega 3-PUFAs in proliferative retinopathy. Circ Res 2010; 107: 495-500.

31. Johnson L, Quinn GE, Abbasi S, et al. Effect of sustained pharmacologic vitamin E levels on incidence and severity of retinopathy of prematurity: a controlled clinical trial. J Pediatr 1989; 114: 827-38.

32. Amadio M, Govoni S, Pascale A. Targeting VEGF in eye neovascularization: What's new?: A comprehensive review on current therapies and oligonucleotide-based interventions under development. Pharmacol Res 2016; 103: 253-69.

33. Autrata R, Krejcírová I, Senková K, Holoušová M, Doležel Z, Borek I. Intravitreal pegaptanib combined with diode laser therapy for stage $3+$ retinopathy of prematurity in zone I and posterior zone II. Eur J Ophtalmol 2012; 22: 687-94.
34. Ramsey DJ, Haddock LJ, Young LH, Eliott D. Complications of subspecialty ophthalmic care: systemic complications from the intravitreal administration of agents that target the vascular endothelial growth factor pathway. Semin Ophtalmol 2014; 29: 263-75.

35. Nuzzi R, Tridico F. Complications of intravitreal antiVEGF drugs: a report on our personal experience. J Clin Exp Ophthalmol 2015; 6: 448.

36. Rajvardhan Azad. Use of intravitreal anti-VEGF: Retinopathy of prematurity surgeons' in Hamlet's dilemma? Indian J Ophtalmol 2011; 59: 421-2.

37. Bancalari A, Schade R, Muñoz T, Lazcano C, Parada R, Peña R. Oral propranolol in early stages of retinopathy of prematurity. J Perinat Med 2016; 44: 499-503.

38. Greenblatt DJ, Koch-Weser J. Adverse reactions to propranolol in hospitalized medical patients: a report from the Boston Collaborative Drug Surveillance Program. Am Heart J 1973; 86: 478-84.

39. Chowers I, Banin E, Hemo Y, et al. Gene transfer by viral vectors into blood vessels in a rat model of retinopathy of prematurity. Br J Ophtalmol 2001; 85: 991-5.

40. Ioannou PA, Vadolas J. Human gene therapy: risks and safety considerations. In: eLS. John Wiley \& Sons Ltd, Chichester. 2006 (http://www.els.net). doi: 10.1038/npg.els.0003946

41. Hunt S. Increased dietary intake of omega-3-PUFA reduces pathological retinal angiogenesis. Ophtalmologe 2007; 104: 727-9.

42. Chen J, Connor KM, Aderman CM, Willett KL, Aspegren OP, Smith LE. Suppression of retinal neovascularization by erythropoietin siRNA in a mouse model of proliferative retinopathy. Invest Ophthalmol Vis Sci 2009; 50: 1329-35.

43. Smith LE, Shen W, Perruzzi C, et al. Regulation of vascular endothelial growth factor dependent retinal neo-vascularization by insulin-like growth factor-1 receptor. Nat Med 1999; 5: 1390-5.

44. Bhola R, Purkiss T, Hunter S, Stewart D, Rychwalski PJ. Effect of granulocyte colony-stimulating factor on the incidence of threshold retinopathy of prematurity. $\mathrm{J}$ AAPOS 2009; 13: 450-3.

45. Johnson L, Bowen FW, Abbasi A et al. Relationship of prolonged pharmacologic serum levels of vitamin $\mathrm{E}$ to incidence of sepsis and necrotizing enterocolitis in infants with birth weight 1,500 grams or less. Pediatrics 1985; 75: 619-38. 